\title{
Health related quality of life in patients with anogenital warts
}

\author{
Sotirios A Koupidis ${ }^{1 *}$, Electra Nicolaidou', Maria Hadjivassiliou', Stefanos Bellos², Petros Skapinakis², \\ Christina Stefanaki ${ }^{1}$, Helen Papadogeorgakis ${ }^{1}$ and Andreas Katsambas ${ }^{1}$
}

\begin{abstract}
Introduction: The health-related quality-of-life (HRQoL) instruments are an important tool for the evaluation of medical outcomes. Sexually transmitted diseases (STDs) influence the patients' life. We aimed to evaluate the HRQoL in patients with anogenital warts at the time of and 1 month after the diagnosis.

Materials and methods: We used the short-form (SF)-36 questionnaire to compare the HRQoL of 91 patients with anogenital warts to 53 control subjects with the same socioeconomic characteristics.

Results: There was no statistical difference in the overall HRQOL measurement between the anogenital wart patients and controls. However, there was an improvement in the scales of vitality (65.22 \pm 15.70 vs. $69.04 \pm 14.11$, respectively; $p<0.05)$ and mental health $(65.00 \pm 20.09$ vs. $69.43 \pm 18.08$, respectively; $p<0.05)$ in anogenital warts patients between the time of diagnosis and 1 month later. Furthermore, there was a significant deterioration in the scale of social functioning (73.47 \pm 22.18 vs. $72.89 \pm 19.28$, respectively; $p<0.05)$. The small sample size is a limitation of our study.

Conclusions: HRQOL does not appear to be influenced in anogenital wart patients, as measured by the generic instrument SF-36. It is therefore important to develop specific instruments for the measurement of HRQOL in this group of patients.
\end{abstract}

\section{Introduction}

Sexually transmitted diseases (STDs) are a group of diseases that are transmitted through sexual intercourse and are caused by a wide variety of pathogenic microorganisms. Until this day, more than 50 micro-organisms have been recognised as a cause of STDs [1]. These diseases comprise a global challenge for health care systems [2-4]. As STDs have reached epidemic dimensions, they are recognized as a considerable threat for public health. In addition, STDs are a cause of acute illness, infertility, disability and death, with serious medical and psychological consequences for millions of people. The STD epidemic is associated with several political, socioeconomic, behavioural, biochemical and biomedical factors.

According to the World Health Organization and Eurostat, there are 28 million new STD cases in Europe

\footnotetext{
* Correspondence: sotirioskoupidis@yahoo.gr

'Sexually Transmitted Infections Unit, $1^{\text {st }}$ Department of Dermatology and Venereology, University of Athens, "Andreas Sygros" Hospital, Athens, Greece Full list of author information is available at the end of the article
}

per annum [3,4]. The highest incidence is observed in urban populations between 15-35 years of age [3,4].

Skin diseases may have a considerable effect on the patient's quality-of-life (QoL). In $20-50 \%$ of patients with skin diseases in secondary care, the decrease in the QoL may be severe enough to classify the patient at risk of developing severe psychosocial impairment or psychiatric morbidity such as clinical depression [5-7].

Human papillomavirus (HPV) infection is the most common cause of STDs worldwide with $50 \%$ of the cases involving individuals aged $15-25$ years $[8,9]$. More than 100 different types of HPV have been identified [10], 30 or 40 of which can infect the mucosa and skin of the anogenital area $[11,12]$. Clinically, anogenital warts consist of epidermal and dermal papules or nodules on the perineum, genitalia, crural folds and anus. They vary in size and can form large, exophytic (cauliflower-like) masses, especially in the moist environment of the perineum. Discrete 1-to 3- mm sessile warts may occur on the penile shaft. Warts may extend

\section{() Biomed Central}


internally into the vagina, urethra and perirectal epithelium [1].

The health-related QoL (HRQoL) is very important for the evaluation of medical outcomes. It is measured with generic and disease-specific instruments. These instruments are more important in fields such as Dermatology where mortality is a relatively rare outcome. There is only 1 specific instrument of measuring HRQoL in patients with anogenital warts [13], which has neither been properly adjusted, nor has it been widely translated to be clinically applied.

In the present study we aimed to evaluate the HRQoL in patients with anogenital warts at the time of diagnosis and at one-month follow-up using the generic instrument short-form (SF)-36 [14,15].

\section{Materials and methods}

Between March and October 2008, a total of 240 patients diagnosed for the first time with anogenital warts in the Sexually Transmitted Infections Unit of the "Andreas Sygros" Hospital for Skin and Venereal Diseases were asked to participate in the study. The study consisted of completing the SF-36 questionnaire both at the time of the diagnosis $\left(t_{0}\right)$ and 1 month later $\left(t_{1}\right)$. A total of 53 healthy individuals who visited the hospital for acquiring a health certificate comprised the control group. The study participants comprising the control group filled in the questionnaire only once.

The SF-36 is a generic, self-administered, multi-item questionnaire measuring $\mathrm{HRQoL}$, which is widely used in health services research. It consists of 8 scales: Physical Functioning (PF), Role limitations due to Physical problems (RP), Bodily Pain (BP), General Health (GH), Vitality (V), Social Functioning (SF), Role limitations due to Emotional problems (RE) and Mental Health $(\mathrm{MH})$ [16-18]. Each scale ranges between 0 (worst health) and 100 (best health). Furthermore, we compared these results with the scores of SF-36 in patients with other diseases as well as in the general Greek population, where this questionnaire has already been adapted and evaluated [19-21].

This Ethical Committee of the Athens Hospital for Skin Diseases "Andreas Sygros" approved of the study. A written informed consent was obtained from all patients at the time of study entry.

The SF-36 scales were scored according to the documented procedures [16]. Higher scores indicate a better HRQoL. All the statistical analyses were performed with STATA S/E 9.2. A p-value $<0.05$ was considered as showing significant results.

\section{Results}

A total of 91 patients completed the study. The dropouts and response rates are presented in Figure 1.

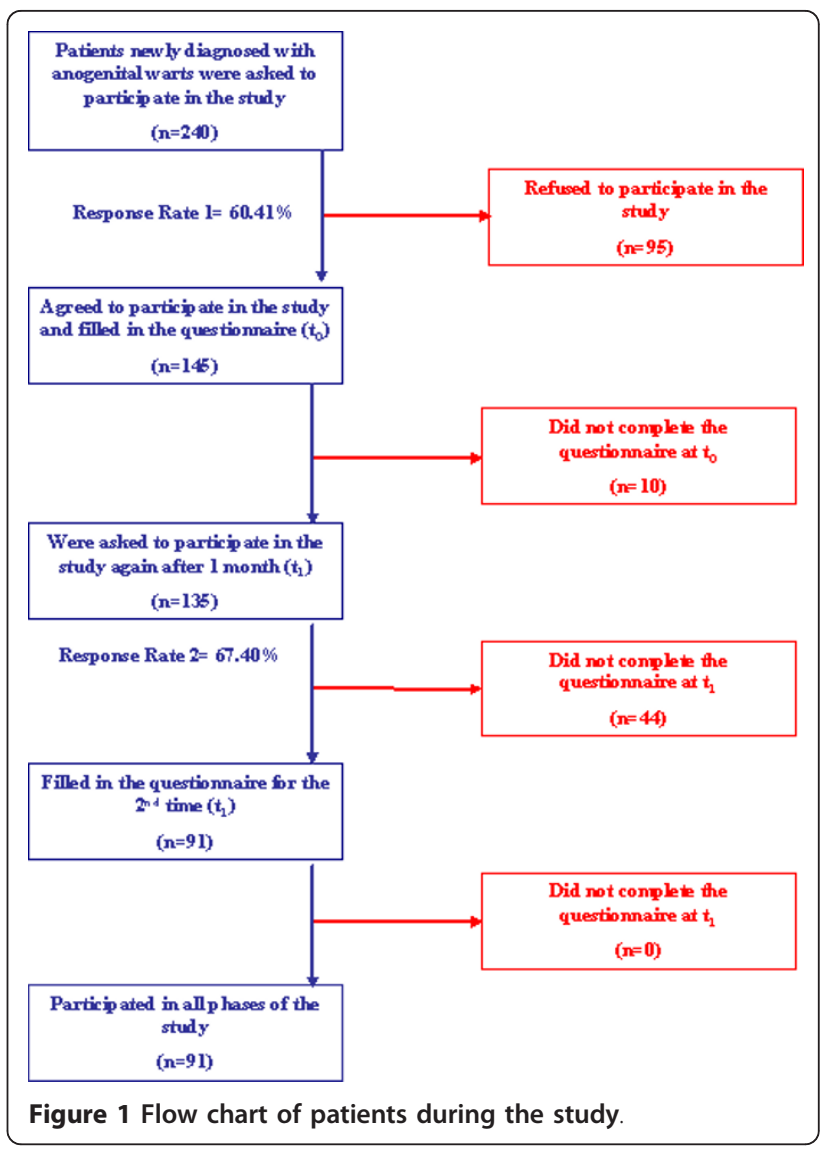

The sociodemographic characteristics of the study participants are presented in Table 1 . The results of the 8 scales of SF-36 between the two time intervals in patients with anogenital warts and in the control group are presented in Table 2. In this Table, the scores of the 8 scales for the general population in Greece were also included.

There was no difference in the scores of SF-36 between the patient and the control groups. In 5 of the 8 scales (PF, BP, GH, RP and RE) there was also no significant difference in the 2 consecutive measurements of the patient group. In contrast, there was a slight but significant improvement in $\mathrm{V}$ and $\mathrm{MH}$ in the patient group between the 2 time intervals. Furthermore, there was a slight but significant deterioration in SF in the patient group between the 2 time intervals.

\section{Discussion}

Our study showed that patients with anogenital warts show an improvement in vitality and mental health 1 month after the establishment of the diagnosis. The possible reasons for this improvement may be the clinical improvement or the clearing of the lesions after 1 month of treatment and the familiarity with the disease. In contrast, our patients showed a slight but significant 
Table 1 Socio-demographic characteristics of the study participants

\begin{tabular}{|c|c|c|}
\hline \multicolumn{3}{|c|}{ Socio-demographic characteristics of the study participants } \\
\hline & $\begin{array}{l}\text { Patients } \\
(\mathrm{n}=91)\end{array}$ & $\begin{array}{l}\text { Controls } \\
(n=53)\end{array}$ \\
\hline Age, Mean & 26.4 & 26.3 \\
\hline [95\% Confidence Interval] & {$[25.0-27.9]$} & {$[24.5-28.2]$} \\
\hline \multicolumn{3}{|l|}{ Gender \% } \\
\hline Male & 73 & 74 \\
\hline Female & 27 & 26 \\
\hline \multicolumn{3}{|l|}{ Age group \% } \\
\hline$<20$ & 7.7 & 9.4 \\
\hline $20-29$ & 71.4 & 67.9 \\
\hline $30-39$ & 14.3 & 17.0 \\
\hline $40-55$ & 6.6 & 5.7 \\
\hline \multicolumn{3}{|l|}{ Marital status \% } \\
\hline Married & 89.01 & 88.68 \\
\hline Single & 6.59 & 5.66 \\
\hline Divorced & 3.30 & 5.66 \\
\hline Widowed & 1.10 & 0 \\
\hline \multicolumn{3}{|l|}{ Education \% } \\
\hline Primary & 1.10 & 1.89 \\
\hline Secondary & 47.25 & 33.97 \\
\hline University & 38.46 & 49.05 \\
\hline $\mathrm{MSc} / \mathrm{PhD}$ & 8.79 & 13.20 \\
\hline No answer & 4.40 & 1.89 \\
\hline \multicolumn{3}{|l|}{ Household income \% } \\
\hline$<500 €$ & 14.29 & 9.43 \\
\hline $501 €-1000 €$ & 30.77 & 26.41 \\
\hline $1001 €-2000 €$ & 23.08 & 33.96 \\
\hline $2001 €-3000 €$ & 9.89 & 9.43 \\
\hline $3001 €-5000 €$ & 8.79 & 16.99 \\
\hline$<5001 €$ & 8.79 & 1.89 \\
\hline No answer & 4.40 & 1.89 \\
\hline \multicolumn{3}{|l|}{ Working status \% } \\
\hline Working & 61.54 & 62.26 \\
\hline $\begin{array}{l}\text { Not working (unemployed, student, } \\
\text { housewifery) }\end{array}$ & 36.26 & 35.85 \\
\hline No answer & 2.20 & 1.89 \\
\hline
\end{tabular}

deterioration in social functioning. This may be the result of feelings of guilt or shame for their condition resulting to avoidance/restriction of social contacts. According to the literature, patients with anogenital warts suffer anxiety about the effect of the disease on their sexual [13,22-27] and social relationships [13,23], the stigma of having contracted a venereal disease $[25,27]$, the uncertain treatment success and time to cure $[13,22,23,26]$ and transmission of the disease to others [13,22-25]. Several studies report that the negative psychological effects of the disease are the most difficult to treat $[23,25,27]$. They include feelings of anger, fear caused by the relationship of HPV to cervical cancer, guilt, depression, self-loathing and worries about the future [13,22-29]. Finally, the literature points to an increased need for more information about the disease and an improved communication between physicians and patients [22,23,25,27].

More male than female patients were recruited in our study. This is because more male patients with STDs seek help for their condition in a hospital for Skin and Venereal Diseases, like ours. Most women consult their gynecologist for conditions like STDs. Furthermore, the small number of women who attended our hospital did not wish to participate in the study.

Our study has some limitations. Firstly, the sample size was relatively small. Nevertheless, it was adequate to reach significant conclusions. In addition, the population of our study was patients attending a public, specialized hospital; it did not include patients from general hospitals, as well as patients from private practitioners. It also did not include more wealthy patients who usually prefer private hospitals to maintain their anonymity, as well as those women who are treated by other specialists (e.g. gynecologists). Therefore one should not generalize the results in such groups if patients.

Based on the above-mentioned arguments, a credible questionnaire/tool is required to measure psychological burden on patients with anogenital warts. The development of a specific questionnaire for measuring HRQoL in patients with anogenital warts, as described by Badia and associates [13], could demonstrate the degree of psychological/social/physical burden of this condition to patients. In addition, use of this questionnaire in different populations (i.e. with different religions, ethical and social beliefs, etc.) will help in drawing conclusions about the relative burden of the condition according to the patients' background.

There are several clinical implications of our study. Firstly, by use of the questionnaire, patients are directly involved and may participate in their treatment more actively. This way the emphasis is shifted from diseaseoriented to patient-oriented treatment. For this reason assessment of the HRQoL has been routinely used as a measure of efficacy in clinical practice and research [30]. Additionally, there is the potential for physicians to receive feedback from the patients regarding the effectiveness of the treatment and their degree of satisfaction. Furthermore, the use of the SF-36 in specific patient subgroups with different religious or cultural background compared to the rest of the Greek population (e. g. Muslims, refugees, etc.) may have a different effect on HRQoL. Finally, the employment of these tools will enable the more objective verification of the success or 
Table 2 HRQoL measured with - SF-36

\begin{tabular}{|c|c|c|c|c|c|}
\hline \multicolumn{6}{|c|}{ HRQoL measured with - SF-36 } \\
\hline Scales & $\begin{array}{c}\text { Patients } \\
\left(\mathrm{n}=91, \mathrm{t}_{0}\right)\end{array}$ & $\begin{array}{c}\text { Patients } \\
\left(\mathrm{n}=91, \mathrm{t}_{1}\right)\end{array}$ & $\begin{array}{l}\text { Controls } \\
(\mathrm{n}=54)\end{array}$ & General population of Greece $(n=1007)$ & \\
\hline \multicolumn{6}{|c|}{ Score } \\
\hline Physical Functioning (PF) & $\begin{array}{c}88.72 \\
\text { (SD: 16.63) } \\
\end{array}$ & $\begin{array}{c}91.57 \\
\text { (SD: 14.89) } \\
\end{array}$ & $\begin{array}{c}88.39 \\
\text { (SD: 13.32) } \\
\end{array}$ & $\begin{array}{c}79.5 \\
\text { (SD: 26.3) } \\
\end{array}$ & NS \\
\hline Bodily Pain (BP) & $\begin{array}{c}82.56 \\
\text { (SD: } 20.35) \\
\end{array}$ & $\begin{array}{c}83.34 \\
\text { (SD: } 22.27) \\
\end{array}$ & $\begin{array}{c}78.11 \\
\text { (SD: } 23.35) \\
\end{array}$ & $\begin{array}{c}72.4 \\
\text { (SD: } 31.9) \\
\end{array}$ & NS \\
\hline General Health (GH) & $\begin{array}{c}64.22 \\
\text { (SD: 15.83) }\end{array}$ & $\begin{array}{c}66.36 \\
\text { (SD: 15.06) }\end{array}$ & $\begin{array}{c}70.66 \\
\text { (SD: 18.02) }\end{array}$ & $\begin{array}{c}66.7 \\
\text { (SD: 23.8) }\end{array}$ & NS \\
\hline Role Physical (RP) & $\begin{array}{c}82.78 \\
\text { (SD: 28.21) }\end{array}$ & $\begin{array}{c}83.14 \\
\text { (SD: 26.78) }\end{array}$ & $\begin{array}{c}84.43 \\
\text { (SD: } 25.11)\end{array}$ & $\begin{array}{c}78.6 \\
\text { (SD: 38.7) }\end{array}$ & NS \\
\hline Role Emotional (RE) & $\begin{array}{c}81.11 \\
\text { (SD: } 32.79)\end{array}$ & $\begin{array}{c}83.13 \\
\text { (SD: 28.92) }\end{array}$ & $\begin{array}{c}83.64 \\
\text { (SD: } 28.95)\end{array}$ & $\begin{array}{c}81.2 \\
\text { (SD: 36.6) }\end{array}$ & NS \\
\hline Vitality (V) & $\begin{array}{c}65.22 \\
\text { (SD: } 15.70)\end{array}$ & $\begin{array}{c}69.04 \\
\text { (SD: } 14.11)\end{array}$ & $\begin{array}{c}68.68 \\
\text { (SD:15.25) }\end{array}$ & $\begin{array}{c}66,0 \\
\text { (SD: } 22.5)\end{array}$ & $p<0.05$ \\
\hline Social Functioning (SF) & $\begin{array}{c}73.47 \\
\text { (SD: } 22.18)\end{array}$ & $\begin{array}{c}72.89 \\
\text { (SD: } 19.28) \\
\end{array}$ & $\begin{array}{c}75.70 \\
\text { (SD:21.98) } \\
\end{array}$ & $\begin{array}{c}81,3 \\
\text { (SD: 28.7) } \\
\end{array}$ & $\mathrm{p}<0.05$ \\
\hline Mental Health (MH) & $\begin{array}{c}65.00 \\
\text { (SD: } 20.09)\end{array}$ & $\begin{array}{c}69.43 \\
\text { (SD: } 18.08)\end{array}$ & $\begin{array}{c}66.22 \\
\text { (SD:19.43) }\end{array}$ & $\begin{array}{c}68,2 \\
\text { (SD: } 21.2)\end{array}$ & $\mathrm{p}<0.05$ \\
\hline
\end{tabular}

NS: not significant.

failure of the therapeutic approach and will also implicate the patient himself/herself in the management of the condition.

\section{Conclusions}

In conclusion, we found that there was an improvement in the scales of vitality and mental health and a deterioration in the scale of social functioning in anogenital warts patients between the time of diagnosis and initiation of treatment and one month later. The small sample size however is a limitation of our study. HRQoL does not appear to be influenced in anogenital wart patients, as measured by the generic instrument SF-36. It is important to develop specific instruments for the measurement of HRQoL in this group of patients.

\section{Conflict of interest}

The authors declare that they have no competing interests.

\section{Authors' contributions sections}

SK participated in the design of this ancillary work, reviewed the literature. He also participated in generating and gathering the data the data and in writing the manuscript. EN participated in generating the data and in writing the manuscript. MH participated in the design of the study and in writing the manuscript. SB Performed the statistical analysis, and drafted the manuscript. PS made critical comments and helped in the interpretation of the results. CS participated in generating and in gathering the data of the study. HP participated in generating and gathering the data of the study. AK participated in the design and coordination of the study. All authors collaborated interactively, and read and approved the final version.

\section{Acknowledgements}

The authors would like to thank the medical staff of Sexually Transmitted Infections Unit, $1^{\text {st }}$ Department of Dermatology and Venereology, University of Athens, "Andreas Sygros" Hospital, Athens, Greece for their help and support.

\section{Author details}

${ }^{1}$ Sexually Transmitted Infections Unit, $1^{\text {st }}$ Department of Dermatology and Venereology, University of Athens, "Andreas Sygros" Hospital, Athens, Greece. ${ }^{2}$ Department of Psychiatry, Medical School, University of loannina, Greece.

Received: 16 February 2011 Accepted: 16 August 2011

Published: 16 August 2011

\section{References}

1. Eichmann AR: Other venereal diseases Fitzpatrick's Dermatology in General Medicine.Edited by: I Freedberg, A Eisen, K Wolff, KF Austen, LA Goldsmith, SI Katz, TB Fitzpatrick, 62003.

2. Chesson HW, Blandford JM, Gift TL, Tao G, Irwin KL: The estimated direct medical cost of sexually transmitted diseases among American youth 2000. Perspect Sex Reprod Health 2004, 36:11-19.

3. WHO: Global prevalence and incidence of selected curable sexually transmitted infections. 2010 [http://www.who.int/HIV_AIDS/GRSTI/index. htm], Accessed on October 10.

4. Eurostat: 2010 [http://www.avert.org/aids-hiv-asia-europe.htm], Accessed on October 10 .

5. Picardi A, Abeni D, Renzi C, Braga M, Puddu P, Pasquini P: Increased psychiatric morbidity in female outpatients with skin lesions on visible parts of the body. Acta Derm Venereol 2001, 81:410-414.

6. Picardi A, Abeni D, Melchi CF, Puddu P, Pasquini P: Psychiatric morbidity in dermatological outpatients: an issue to be recognized. $\mathrm{Br} J$ Dermatol 2000, 143:983-991. 
7. Picardi A, Adler DA, Abeni D, Chang H, Pasquini P, Rogers WH, Bungay KM: Screening for depressive disorders in patients with skin diseases: a comparison of three screeners. Acta Derm Venereol 2005, 85:414-419.

8. Nicolaidou E, Katsambas AD: The burden of human papillomavirus infections and the expected impact of new vaccines. Expert Rev Vaccines 2007, 6:475-477.

9. Ho GY, Bierman R, Beardsley L, Chang CJ, Burk RD: Natural history of cervicovaginal papillomavirus infection in young women. $N$ Engl J Med 1998, 338:423-428

10. Benenson A: Control of communicable diseases manual. Washington DC: American Public Health Association; 1995.

11. Kjaer SK, Chackerian B, van den Brule AJ, Svare El, Paull G, Walbomers JM, Schiller JT, Bock JE, Sherman ME, Lowy DR, Meijer CL: High-risk human papillomavirus is sexually transmitted: evidence from a follow-up study of virgins starting sexual activity (intercourse). Cancer Epidemiol Biomarkers Prev 2001, 10:101-106.

12. Smith JS, Lindsay L, Hoots B, Keys J, Franceschi S, Winer R, Clifford GM: Human papillomavirus type distribution in invasive cervical cancer and high-grade cervical lesions: a meta-analysis update. Int J Cancer 2007, 121:621-632.

13. Badia X, Colombo JA, Lara N, Llorens MA, Olmos L, Sainz de los Terreros M, Varela JA, Vilata JJ: Combination of qualitative and quantitative methods for developing a new Health Related Quality of Life measure for patients with anogenital warts. Health Qual Life Outcomes 2005, 3:24.

14. Aaronson NK, Acquadro C, Alonso J, Apolone G, Bucquet D, Bullinger M, Bungay K, Fukuhara S, Gandek K, Keller S: International Quality of Life Assessment (IQOLA) Project. Qual Life Res 1992, 1:349-351.

15. Garratt A, Ruta D, Abdalla M, Buckingham J, Russell I: The SF-36 health survey questionnaire: an outcome measure suitable for routine use within the NHS? Br Med J 1993, 306:1440-1444.

16. Ware J, Snow K, Gandek B, Kosinski M: SF-36 Health Survey Manual and Interpretation Guide. Boston: Medical Center; 1993.

17. Ware J: SF-36 health survey update. Spine 2000, 25:3130-3139.

18. Alonso J, Ferrer M, Gandek B, Ware JE Jr, Aaronson NK, Mosconi P, Rasmussen NK, Bullinger M, Fukuhara S, Kaasa S, Leplege A, IQOLA Project Group: Health-related quality of life associated with chronic conditions in eight countries: results from the International Quality of Life Assessment (IQOLA) Project. Qual Life Res 2004, 13:283-298.

19. Pappa E, Kontodimopoulos N, Papadopoulos AA, Niakas D: Assessing the socio-economic and demographic impact on health-related quality of life: evidence from Greece. Int J Public Health 2009, 54:241-249.

20. Anagnostopoulos F, Niakas D, Pappa E: Construct validation of the Greek SF-36 Health Survey. Qual Life Res 2005, 14:1959-1965.

21. Pappa E, Kontodimopoulos N, Niakas D: Validating and norming of the Greek SF-36 Health Survey. Qual Life Res 2005, 14:1433-1438.

22. Maw RD, Reitano M, Roy M: An international survey of patients with genital warts: perceptions regarding treatment and impact on lifestyle. Int J STD AIDS 1998, 9:571-578.

23. Maggino T, Casadei D, Panontin E, Fadda E, Zampieri MC, Dona MA Dona MA, Solda M, Altoe G: Impact of an HPV diagnosis on the quality of life in young women. Gynecol Oncol 2007, 107:S175-179.

24. Graziottin A, Serafini A: HPVinfection in women: psychosexual impact of genital warts and intraepithelial lesions. J Sex Med 2009, 6:633-645.

25. Clarke P, Ebel C, Catotti DN, Stewart S: The psychosocial impact of human papillomavirus infection: implications for health care providers. Int J STD AIDS 1996, 7:197-200.

26. Sheppard S, White M, Walzman M: Genital warts: just a nuisance? Genitourin Med 1995, 71:194-195.

27. Hammarlund K, Lundgren I, Nystrom M: To contract genital warts - a risk of losing love? Experiences of Swedish men living with genital warts. Int J Mens Health 2007, 6:100-114.

28. Kitchener HC: The role of human papillomavirus in the genesis of cervical cancer. Cancer Treat Res 1994, 70:29-41.

29. Walboomers JM, Jacobs MV, Manos MM, Bosch FX, Kummer JA, Shah KV, Snijders PJ, Peto J, Meijer CJ, Muñoz N: Human papillomavirus is a necessary cause of invasive cervical cancer worldwide. J Pathol 1999, 189:12-19.

30. Kondo-Endo K, Ohashi Y, Nakagawa H, Katsunuma T, Ohya Y, Kamibeppu K, Masuko I: Development and validation of a questionnaire measuring quality of life in primary caregivers of children with atopic dermatitis (QPCAD). Br J Dermatol 2009, 161:617-625. doi:10.1186/1477-7525-9-67

Cite this article as: Koupidis et al:: Health related quality of life in patients with anogenital warts. Health and Quality of Life Outcomes 2011 9:67.

\section{Submit your next manuscript to BioMed Central and take full advantage of:}

- Convenient online submission

- Thorough peer review

- No space constraints or color figure charges

- Immediate publication on acceptance

- Inclusion in PubMed, CAS, Scopus and Google Scholar

- Research which is freely available for redistribution

Submit your manuscript at www.biomedcentral.com/submit
C Biomed Central 